\title{
The 'Coral Bulker' Fuel Oil Spill on the North Coast of Portugal: Spatial and Temporal Biomarker Responses in Mytilus galloprovincialis
}

\author{
SUSANA MARIA MOREIRA, ${ }^{1,2, *}$ M. MOREIRA-SANTOS, ${ }^{3}$ R. RIBEIRO ${ }^{3}$ AND GUILHERMINO L. ${ }^{1,2}$ \\ ${ }^{1}$ Instituto de Ciências Biomédicas de Abel Salazar, Departamento de Estudos de Populações, \\ Laboratório de Ecotoxicologia, Universidade do Porto, Largo Professor Abel Salazar, 2, \\ 4099-003 Porto, Portugal \\ ${ }^{2}$ Centro Interdisciplinar de Investigação Marinha e Ambiental, Rua dos Bragas, 289, \\ 4050-123 Porto, Portugal \\ ${ }^{3}$ Instituto do Ambiente e Vida, Departamento de Zoologia da Universidade de Coimbra, \\ Largo Marquês de Pombal, 3004-517 Coimbra, Portugal
}

Accepted 9 September 2003

\begin{abstract}
In December 2000, the ship 'Coral Bulker' ran aground at the entrance of the port of Viana do Castelo (North-west coast of Portugal). A large amount of fuel oil was spilled and part of it reached the shore. To evaluate the spatial and temporal impact of this oil spill, a field study, and several laboratory toxicity tests were performed using Mytilus galloprovincialis as biological indicator of environmental contamination and the biomarkers glutathione S-transferases (GSTs) and acetylcholinesterase (AChE) as indicative criteria. Fifteen days after the oil spill, mussels collected at stations located near the ship presented higher and lower values of GSTs and AChE activity, respectively. These results, and those obtained in the laboratory toxicity tests, evidence that these biomarkers were sensitive indicators of exposure to this kind of pollution and were able to monitor a spatial impact of the oil spill of at least $10 \mathrm{~km}$, confirming the higher level of contamination near the ship and a contamination gradient along the sampling stations. One year after the accident, such a contamination gradient was no longer evident. This study highlight the potential suitability of a biomarker approach for assessing spatial and temporal impacts of marine pollution accidents, such as fuel oil spills, suggesting the inclusion of these biomarkers in risk assessment studies, as cost-effective and early warning recognized tools. Major advantages and limitations of the biomarker approach used in this study are further discussed.
\end{abstract}

Keywords: fuel oil spill; Mytilus galloprovincialis; biomarkers; acetylcholinesterase; glutathione S-transferases

\section{Introduction}

In the last decades, the rapid increase of anthropogenic activities has lead to a continual influx of

*To whom correspondence should be addressed: Tel.: + 3512234018 00; Fax: + 351223390608 ; E-mail: smmoreira@cimar.org both organic and inorganic xenobiotics into estuaries and coastal waters, including polyaromatic hydrocarbons (PAHs), polychlorinated biphenyls (PCBs), organophosphorus compounds and heavy metals. Marine hydrocarbon contamination, particularly, has become a major environmental problem. In December 2000, the wood-carrying 
ship 'Coral Bulker' ran aground at the entrance of the port of Viana do Castelo (North coast of Portugal). The ship was carrying some 700 tons of fuel oil and a large amount of it was spilled and moved southwards parallel to the coast along approximately $20 \mathrm{~km}$ of shoreline.

Marine mussels, such as Mytilus spp., are widely used in pollution monitoring programmes in coastal waters (Beliaeff et al., 1997; Goldberg et al., 1975). As filter feeders, these animals are able to accumulate in their tissues a wide range of both organic and inorganic contaminants present in their environment. In addition, they are semisessile and euryhaline organisms with a wide geographical distribution; characteristics that make them particularly suitable to assess the concentration of selected chemicals as well as to investigate their biological impact (Viarengo and Canesi, 1991). Chemical analyses of tissue concentrations are able to detect a wide range of contaminants. However, this approach does not provide any indication of biological significance and deleterious effects on the biota (Bucheli and Fent, 1995). Therefore, the measurement of biological effects caused by contaminants has become of major issue in environmental risk assessment. In order to provide information on these contaminant effects on organisms and population health, methods for identification and measuring the biological impact are now being incorporated into mussel watch programmes (Veldhuizen-Tsoerkan et al., 1991; Narbonne et al., 1999; Porte et al., 2001b). Recently, there has been a significant increase in the use of biomarkers for assessing the impact of chemicals in coastal environments (Carajaville et al., 2000). Since the biological effects of these chemicals are usually first displayed at the molecular/biochemical level, the use of biochemical alterations as environmental biomarkers make possible to anticipate and predict effects that may occur later at higher levels of organisation (i.e., population, community, and ecosystem), providing earlier warning signals of potential pollution effects (Peakall, 1992).

In mussels, two commonly used biochemical biomarkers are glutathione S-transferases (GSTs; EC 2.5.1.18) and acetylcholinesterase (AChE; EC 3.1.1.7). GSTs, an important enzymatic family of phase II of the biotransformation process, catalyse the conjugation of reduced glutathione
(GSH) with a wide group of compounds bearing eletrophilic centres, playing an important role in the detoxification and excretion of endogenous compounds, xenobiotics, and products of oxidative stress (Clark, 1989). Because these isoenzymes are inducible by a wide range of chemicals, it has been suggested that the levels of GSTs in mussels might be an useful index as an indicator of conjugating activities and exposure to chemical pollution (Fitzpatrick and Sheehan, 1993). AChE is involved in the transmission of nerve impulses and its inhibition has been widely used as a specific biomarker for organophosphate and carbamate pesticides (Thompson, 1999). Recently, some studies provided evidence that other environmental contaminants, such as metals and surfactants, may also be ecologically relevant anti-cholinesterases agents (Payne et al., 1996; Guilhermino et al., 1998). AChE activity has been proposed and used as an indicator of possible neurotoxicity (Peakall, 1992). Biochemical biomarkers have been applied in the assessment of the impact of several oil spillages using marine mussels as sentinel organisms (Solé et al., 1996; Peters et al., 1999; Porte et al., 2000). However, as far as we know, the assessment of long-term effects has been studied only in few cases (Porte et al., 2000).

To evaluate the spatial and temporal impact of the 'Coral Bulker' oil spill, a field study and several laboratory toxicity tests were performed, using the mussel M. galloprovincialis as biological indicator of environmental contamination. The biomarkers GSTs and AChE were used as indicative criteria. Since acclimation period and laboratory test conditions may influence the biomarker responses, these factors were also investigated in this study. The comparison between the performance of the biomarkers used and standard acute bioassays results, which examine lethal effects, can highlight the usefulness of the biomarker approach. For this reason, standard acute bioassays were also performed using the brine shrimp Artemia franciscana (Artoxkit $^{\mathrm{TM}}$ ) and the rotifer Brachionus plicatilis (Rotoxkit-M ${ }^{\mathrm{TM}}$ ) as test organisms. Both Artemia spp. and rotifers have long been used in aquatic toxicology and are widely accepted as test organisms to evaluate effects of potential pollutants on marine and coastal waters (Van Steertegem and Persoone, 1993; Snell and Janssen, 1998). 


\section{Materials and methods}

\section{Study area}

In order to undertake the integrated monitoring strategy for the spatial and temporal impact evaluation of the oil spill, four stations were selected along the northwest Portuguese coast, along a presumed decreasing contamination gradient (southwards: station 1-4). Figure 1 schematically shows the localization of the study area. Station 1 (S1), located at the entrance of the industrial port of Viana do Castelo and closer to the ship, was apparently the most contaminated station, presenting large amounts of oil both in the sandy and rocky shore. Station 2 (S2), located approximately $10 \mathrm{~km}$ south from the accident point, seemed also affected by the oil spill but to a lesser extent, while station 3 (S3), located about $20 \mathrm{~km}$ south from the ship, was apparently not affected. Station 4 (S4), approximately $40 \mathrm{~km}$ south from Viana do Castelo port, was selected as a reference point. All sampling stations were sandy and rocky shores and with exception to S1, were located in small fishery villages, far from main pollution sources such as urban and industrial settlements.

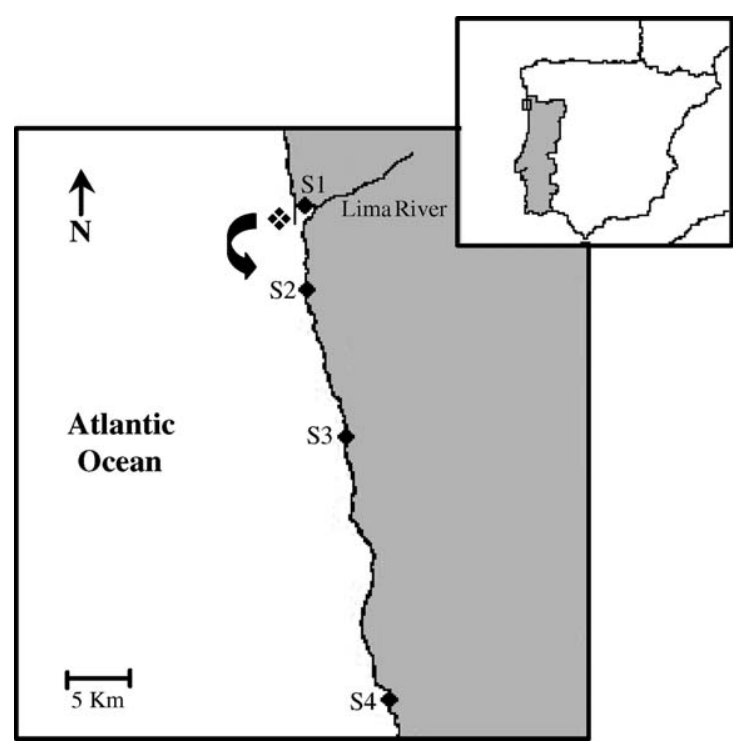

Figure 1. Map of study area, showing the grounding site of the 'Coral Bulker' (*) and the sampling stations (S1, S2, S3 stations along the presumed decreasing contamination gradient; S4 - reference station). The arrow represents the movement of the fuel oil spilled.
Field study with M. galloprovincialis

Thirty adult mussels ( $M$. galloprovincialis) of undetermined sex and selected size (mean anterior-posterior shell length of 3 to $4 \mathrm{~cm}$ ) were handpicked, at low tide in the intertidal zone of the four sampling stations, at two sampling dates: 15 days and 1 year after the release of oil from the ship. Organisms were placed in thermally insulated boxes, previously filled with local water, and transported to the laboratory within $1-2 \mathrm{~h}$ of collection. In the laboratory, mussels were sacrificed and selected tissues were immediately removed and used for biomarkers quantification.

\section{Laboratory toxicity tests}

Sample collection and elutriate preparation At the first sampling date, residues of oil were also collected from the rocky shore of $\mathrm{S} 1$ and sediment samples from the sandy shore of S1, S2, and S3; all samples were placed in black airtight high-density polyethylene containers and stored at $4{ }^{\circ} \mathrm{C}$ until use. Water samples were also simultaneously collected at these stations. Since the results of the field study confirmed the rather pristine condition of S4 (see results of the field study), sediment and water samples from this station were not included in the laboratory toxicity analysis. Residues of fuel oil from S1 were used to prepare an elutriate solution (elutriate 1A) according to the following procedure: leaching (100 g residue per litre of water) was performed with ASPM reconstituted seawater of 35-g/1 salinity, hereafter designated as ASPM medium (Guillard, 1983), in a Jenway 1000 stirrer for $6 \mathrm{~h}$ at $20 \pm 1{ }^{\circ} \mathrm{C}$; after $24 \mathrm{~h}$, solid and liquid (elutriate) phases were separated by decantation. Elutriate solutions from sediment samples collected from the sandy shore of S1, S2 and S3 (elutriates 1B, 2 and 3, respectively) were prepared based on German Standard Methods (DIN, 1985) accordingly to the following procedure: leaching (100 g sediment per litre of water) was performed with ASPM medium, in an orbital shaker (LH Fermentation, series F200) at $180 \mathrm{rpm}$ and $20 \pm 1{ }^{\circ} \mathrm{C}$; after $24 \mathrm{~h}$, solid and liquid (elutriate) phases were separated by centrifugation, using a Sigma 3-10 Bench centrifuge, at $4500 \mathrm{rpm}$ during 5 min. All water and elutriate samples were filtered through a $55 \mu \mathrm{m}$ nylon mesh and frozen at $-20{ }^{\circ} \mathrm{C}$ 
Table 1. Physico-chemical parameters (salinity, conductivity, and $\mathrm{pH}$ ) of water samples collected from the three sampling stations (S1, S2, S3 - stations along the presumed decreasing contamination gradient) and of elutriate 1A (elutriate prepared from oil residues collected from the rocky shore of $\mathrm{S} 1$ ) and elutriate 1B, 2 and 3 (elutriates prepared from sediment samples collected from the sandy shore of S1, S2 and S3, respectively)

\begin{tabular}{lllll}
\hline & & $\begin{array}{l}\text { Salinity } \\
(\mathrm{g} / \mathrm{l})\end{array}$ & $\begin{array}{l}\text { Conductivity } \\
(\mathrm{mS} / \mathrm{cm})\end{array}$ & $\mathrm{pH}$ \\
\hline \multirow{4}{*}{ Station 1 } & Water & 10.7 & 18.3 & 7.55 \\
& Elutriate 1A & 32.6 & 51.4 & 7.85 \\
Station 2 & Elutriate 1B & 33.0 & 51.6 & 8.12 \\
& Water & 32.1 & 51.0 & 7.94 \\
Station 3 & Elutriate 2 & 32.2 & 51.2 & 7.89 \\
& Water & 28.2 & 45.3 & 7.57 \\
& Elutriate 3 & 32.8 & 51.6 & 7.7 \\
\hline
\end{tabular}

until use. Physical-chemical parameters (salinity, conductivity and $\mathrm{pH}$ ) were measured in all elutriate and water samples and are summarized in Table 1 . Salinity and conductivity were measured with a WTW LF 330 meter, and $\mathrm{pH}$ measurements were performed using a WTW 340-A meter.

Toxicity tests with M. galloprovincialis With respect to laboratory toxicity tests performed with M. galloprovincialis, adult mussels of undetermined sex and selected size (mean anteriorposterior shell length of 3 to $4 \mathrm{~cm}$ ) were collected from the intertidal zone of S4, since the results of the field study confirmed its suitability as a reference station (see results of the field study). Mussels were immediately brought to the laboratory in local water and inside thermally insulated boxes, and acclimated in ASPM medium, to a temperature of $20 \pm 1{ }^{\circ} \mathrm{C}$ and a photoperiod of $12 \mathrm{~h} \mathrm{~L}: 12 \mathrm{~h} \mathrm{D}$, for $48 \mathrm{~h}$ before being used in experiments. Toxicity tests were performed with several dilutions of the elutriate samples $(100,75,50,25,12.5,6.25$, and $0 \%$ of elutriate 1A, 1B, 2 and 3), using ASPM medium as dilution water. Four mussels were exposed, in glass vials, in $800 \mathrm{ml}$ of each test solution for $96 \mathrm{~h}$ at $20 \pm 1{ }^{\circ} \mathrm{C}$, with gentle aeration. Three replicates per treatment were performed. Animals were not fed during both the acclimation and test periods. Since both acclimation period and laboratory test conditions must be taken into consideration when studying biochemical responses, 48 mussels were sacrificed at three different periods: just after sample collection in the field (time $T-0 \mathrm{~h}$ ), after the $48 \mathrm{~h}$ acclimation period in the laboratory (time $T-48 \mathrm{~h}$ ), and at the end of laboratory toxicity tests (time $T$ $144 \mathrm{~h}$, corresponding to mussels exposed to a $48 \mathrm{~h}$ acclimation period followed by a $96 \mathrm{~h}$ toxicity test at $0 \%$ of elutriate $1 \mathrm{~A}, 1 \mathrm{~B}, 2$, and $3)$. At the end of acclimation and test periods, mussels were sacrificed and selected tissues were immediately removed and used for biomarkers quantification.

Toxicity tests with $\mathrm{A}$. franciscana and $\mathrm{B}$. plicatilis Acute, $24 \mathrm{~h}$, laboratory toxicity tests were also conducted with the brine shrimp A. franciscana and the rotifer $B$. plicatilis, following the Artoxkit ${ }^{\mathrm{TM}}$ (SOP, 1990) and Rotoxkit-M ${ }^{\mathrm{TM}}$ (SOP, 1994) protocols, respectively. Toxicity tests were performed using several dilutions of field water $(100,75,50$, $25,12.5,6.25$, and $0 \%$ of water from S1, S2, and S3) and sediment elutriate $(100,75,50,25,12.5,6.25$, and $0 \%$ of elutriate $1 \mathrm{~B}, 2$ and 3 ) samples, using ASPM medium as dilution water.

\section{Biomarkers quantification}

Haemolymph and gills of M. galloprovincialis were used as biological material for the quantification of AChE and GSTs activities, respectively. Haemolymph was collected with a syringe from the central part of the posterior adductor muscle and diluted (1:4) with ice-cold phosphate buffer $(0.1 \mathrm{M}, \mathrm{pH}=7.2)$. In order to prevent mixing of mantle fluid into the haemolymph, mantle fluid was previously drained from the mussel. Samples were then normalized to a protein content of $0.5 \mathrm{mg} / \mathrm{ml}$, kept on ice and used on the same day to prevent alterations during storage.

Gills were immediately removed and put on icecold phosphate buffer (0.1 M, pH =6.5). Samples were then homogenized, using an Ystral $\mathrm{GmBH}$ Dottingen homogeniser, and kept on ice during the homogenization. Gills homogenates were stored at $-80{ }^{\circ} \mathrm{C}$ for no more than 3 days. Previous experiments performed in our laboratory indicated that there is no significant alteration of GSTs activity in frozen gills of M. galloprovincialis during this short period of storage. Gills homogenates were 
centrifuged at $9000 \times g$ during $30 \mathrm{~min}\left(\right.$ at $4{ }^{\circ} \mathrm{C}$ ), using a Sigma $3 \mathrm{~K} 30$ refrigerated centrifuge, and the supernatants were normalized to approximate protein concentration of $0.8 \mathrm{mg} / \mathrm{ml}$.

Enzymatic activities were evaluated in triplicate, at $25{ }^{\circ} \mathrm{C}$, and expressed in Units (U) per $\mathrm{mg}$ of protein, being one unit defined as a nmol of substrate hydrolysed per minute. The activity of AChE was determined by the Ellman method (Ellman et al., 1961) adapted to microplate, as described in Guilhermino et al. (1996). The activity of GSTs was determined by the method of Habig et al. (1974), adapted to microplate, using 1-chloro-2,4dinitrobenzene (CDNB) as substrate (Frasco et al., 2002). The enzymatic activities were expressed in Units (U) per mg of protein, being one unit defined as a nmol of substrate hydrolysed per minute. The protein content of the samples was determined by the Bradford method (Bradford, 1976) adapted to microplate, as described in Frasco et al. (2002), using $\gamma$-bovine globulins as standard. All determinations were performed in a Labsystem Multiskan EX microplate reader.

\section{Data analysis}

Concerning the field study performed with M. galloprovincialis, 1-way analysis of variance (1way ANOVA) was used to test differences of AChE and GSTs activities among sampling stations, at each sampling date, followed by the Tukey HSD multiple comparisons test (Zar, 1996). The comparison of enzymatic activities between sampling date, for each sampling station, was determined by the Student's $t$-test for independent samples. Biomarker data from the laboratory toxicity tests performed with M. galloprovincialis were analyzed by nested-ANOVA, followed by the Dunnett multiple comparisons test (Zar, 1996). The effects of acclimation period and laboratory test conditions on enzymatic activities were analyzed using 1-way ANOVA. The significance level was 0.05.

\section{Results}

Field study with M. galloprovincialis

The results of the field study performed with $M$. galloprovincialis, in both sampling dates, are presented in Figure 2. Concerning the first sampling date, carried 15 days after the release of oil from the ship, statistically significant differences on GSTs (1-way ANOVA: $F=73.65, \mathrm{df}=3,116$, $p<0.05$ ) and AChE (1-way ANOVA: $F=60.77$; $\mathrm{df}=3,116, p<0.05)$ activities were found among sampling stations. Mussels collected at S1, located near the ship and apparently the most affected by the fuel oil spill, presented the highest and the lowest values of GSTs and AChE activity, respectively. An increase of GSTs activity and a decrease of AChE activity along the presumed increasing
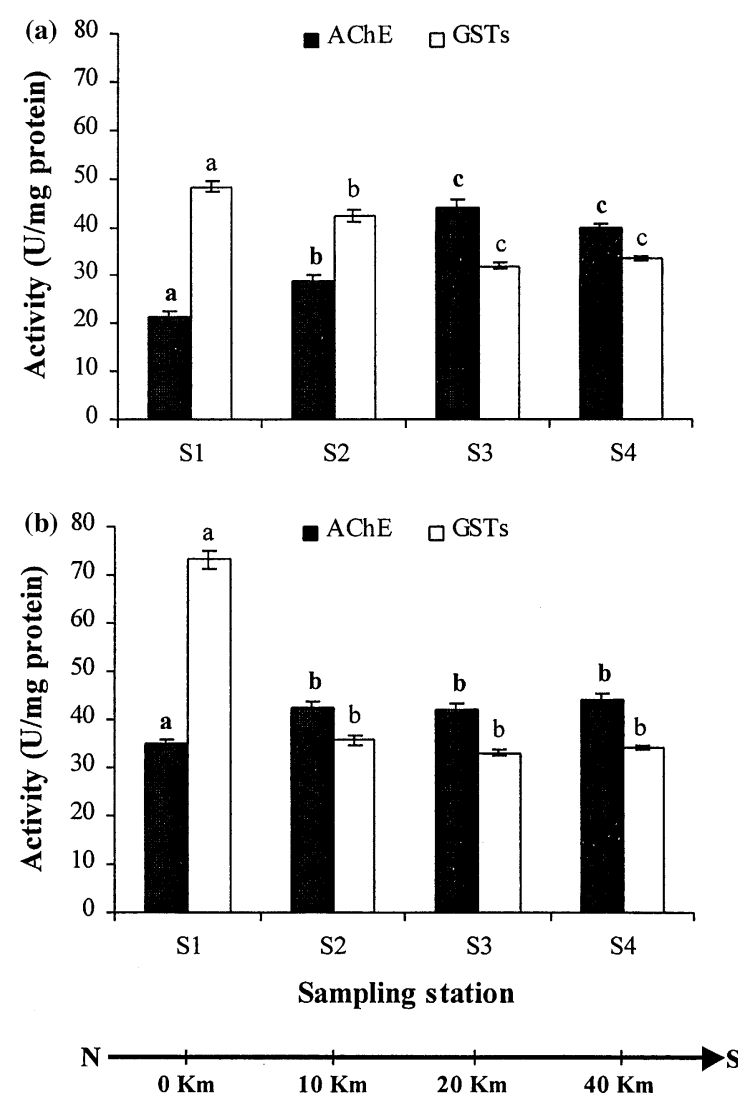

Figure 2. Acetylcholinesterase (AChE) and glutathione S-transferases (GSTs) activities of Mytilus galloprovincialis haemolymph and gills, respectively, collected from the four sampling stations at two sampling dates: 15 days (a) and one year (b) after the fuel oil spill. The arrow placed at the bottom of the graphics indicates the estimated distance from the grounding site of the 'Coral Bulker' to the sampling stations ( $\mathrm{S} 1, \mathrm{~S} 2, \mathrm{~S} 3$ - stations along the presumed decreasing contamination gradient; $\mathrm{S} 4$ - reference station). Values represent the mean of 30 individuals and the correspondent standard error bars. Distinct letters (a, b, c) represent statistically significant differences between sampling stations, for each biomarker $(p<0.05)$. 
contamination gradient were observed. No statistically significant differences on both enzymatic activities were observed between S3 and S4 (Figure 2A). One year after the accident, statistically significant differences on GSTs (1-way ANOVA: $F=257.06, \mathrm{df}=3,116, p<0.05)$ and AChE $(1-$ way ANOVA: $F=10.17$; df $=3,116, p<0.05$ ) activities were still found among sampling stations. As observed in the first sampling date, S1 presented the highest and the lowest values of GSTs and AChE activity, respectively. No statistically significant differences on both enzymatic activities were observed among the other sampling stations (Figure 2B).

The comparison of enzymatic activities between sampling dates, for each sampling station, showed that 1 year after the accident, mussels collected at S1 presented higher values of GSTs ( $t$-test: $t=11.22$, df $=58, p<0.05)$ and AChE ( $t$-test: $t=8.09, \mathrm{df}=58, p<0.05)$ activities, comparing to the levels obtained at the first sampling date. Concerning S2, a significant decrease of GSTs activity was observed ( $t$-test: $t=4.04$, df $=58$, $p<0.05)$, while the value of AChE activity increased ( $t$-test: $t=7.16, \mathrm{df}=58, p<0.05$ ). In mussels collected at S3 and S4, no statistically significant differences were observed between the two sampling dates on both GSTs activities [ $t$-test: $t=1.37(\mathrm{~S} 3), t=0.83(\mathrm{~S} 4), \mathrm{df}=58, p>0.05]$ and AChE [ $t$-test: $t=0.87(\mathrm{~S} 3), t=2.48(\mathrm{~S} 4), \mathrm{df}=58$, $p>0.05]$.

\section{Laboratory toxicity tests}

Toxicity tests with M. galloprovincialis Considering the laboratory toxicity tests performed with $M$. galloprovincialis, a significant increase of GSTs (nested-ANOVA: $F=87.02$, df $=6,14, p<0.05$ ) and a significant inhibition of AChE (nestedANOVA: $F=3.76$, df $=6,14, p<0.05$ ) activities were observed in the tests performed with elutriate 1 A (the elutriate prepared from the fuel oil residues from the rocky shore of S1) (Figure 3). A similar pattern was observed for both enzymes in the tests performed with the elutriate solution prepared from the sediment from the sandy shore of S1 (elutriate 1B): the activity of GSTs was significantly enhanced (nested-ANOVA: $F=100.16$, $\mathrm{df}=6,14, p<0.05)$ and the activity of AChE was significantly depressed (nested-ANOVA: $F=21.43$, df $=6,14, p<0.05$ ), even at the lowest percentage of elutriate tested (Figure 3). Similar results, although less marked, were observed in the laboratory toxicity tests with the elutriate 2 (Figure 3). Comparatively to the control, a significant increase of GSTs activity was also observed at low percentages of elutriate (nestedANOVA: $F=27.82, \mathrm{df}=6,14, p<0.05)$. AChE activity was significantly inhibited, but only at the highest concentration of this elutriate (nestedANOVA: $F=3.80, \mathrm{df}=6,14, p<0.05)$. No significant changes were observed in GSTs (nestedANOVA: $F=0.40$, df $=6,14, p>0.05)$ and AChE activities (nested-ANOVA: $F=0.31$, $\mathrm{df}=6,14, p>0.05)$ in the toxicity tests performed with elutriate 3 .

To determine the influence of the acclimation period and laboratory test conditions on the enzymatic activities, GSTs and AChE levels were measured at three distinct times: just after the collection in the field $(T-0 \mathrm{~h})$; after a $48 \mathrm{~h}$ acclimation period in the laboratory $(T-48 \mathrm{~h})$; and at the end of the $96 \mathrm{~h}$ toxicity tests, which correspond to levels measured at $0 \%$ of elutriate $1 \mathrm{~A}, 1 \mathrm{~B}, 2$ and $3(T-144 \mathrm{~h})$. No significant changes were observed for GSTs (1-way ANOVA: $F=0.47$, df $=2,141$, $p>0.05)$ and AChE activities (1-way ANOVA: $F=0.21$, df $=2,141, p>0.05)$, among sampling times (Table 2).

Toxicity tests with A. franciscana and B. plicatilis With respect to $24 \mathrm{~h}$ bioassays with $A$. franciscana and $B$. plicatilis, the validity criterion recommended in the Artoxkit ${ }^{\mathrm{TM}}$ (SOP, 1990) and Rotoxkit-M ${ }^{\mathrm{TM}}$ (SOP, 1994) protocols for an acute bioassay to be valid was achieved, that is the percentage of dead organisms in the control should not exceed $10 \%$. All bioassays performed, either with water or elutriate samples, were unable to detect significant differences among treatments since mortality never exceed $10 \%$.

\section{Discussion}

Recently, a number of biochemical biomarkers have been applied in the assessment of the impact of several oil spillages using marine mussels 

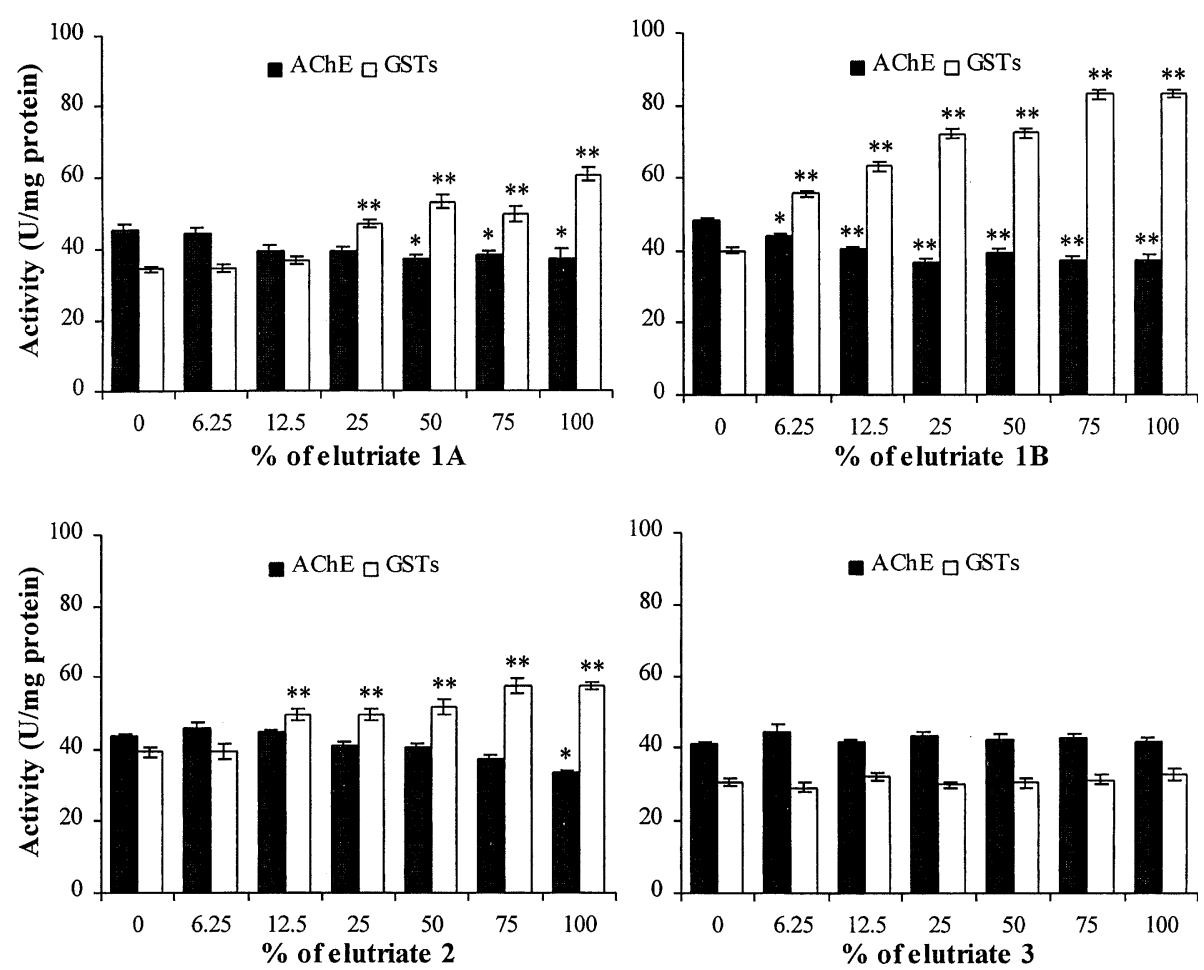

Figure 3. Acetylcholinesterase (AChE) and glutathione S-transferases (GSTs) activities of Mytilus galloprovincialis haemolymph and gills, respectively, after the $96 \mathrm{~h}$ laboratory toxicity tests using several dilutions of elutriate solutions prepared from oil residues collected from the rocky shore of S1 (Elutriate 1A) and from sediment samples collected from the sandy shore of S1 (Elutriate 1B), S2 (Elutriate 2) and S3 (Elutriate 3). Values represent the average of three replicates (four mussels per replicate) and the correspondent standard error bars. $(p<0.05)$ and $* *(p<0.001)$ represent significant differences from control.

Table 2. Values of acetylcholinesterase (AChE) and glutathione S-transferases (GSTs) activities of Mytilus galloprovincialis haemolymph and gills, respectively, measured at three distinct times: just after the collection of mussels in the field $(T-0 \mathrm{~h})$; after a $48 \mathrm{~h}$ acclimation period in the laboratory ( $T-48 \mathrm{~h}$ ); and at the end of the $48 \mathrm{~h}$ acclimation period followed by a $96 \mathrm{~h}$ toxicity tests, which correspond to levels measured in test controls $(T-144 \mathrm{~h})$. Values represent the average $(n=48) \pm$ standard deviation

\begin{tabular}{lll}
\hline Sampling time & $\begin{array}{l}\text { GSTs activity } \\
\text { (U/mg protein) }\end{array}$ & $\begin{array}{l}\text { AChE activity } \\
\text { (U/mg protein) }\end{array}$ \\
\hline$T-0 \mathrm{~h}$ & $34.28 \pm 3.48$ & $43.97 \pm 7.14$ \\
$T-48 \mathrm{~h}$ & $34.98 \pm 2.87$ & $44.16 \pm 5.16$ \\
$T-144 \mathrm{~h}$ & $34.66 \pm 4.07$ & $44.68 \pm 4.24$ \\
\hline
\end{tabular}

as sentinel organisms (Solé et al., 1996; Peters et al., 1999; Porte et al., 2000). In an oil spill, a great variety of compounds, such as PAHs and metals, in various proportions are released and in addition to the immediate damage they may cause to natural populations, long-term effects resulting from continuous sub-lethal exposure to these compounds must also be evaluated (Clark, 1986). However, as far as we know, the assessment of long-term effects on local mussel populations, caused by oil spills, has received little attention (Porte et al., 2000). The present study proposed to assess the spatial and temporal impact of a fuel oil spill using the mussel M. galloprovincialis as biological indicator and two-biochemical biomarkers, GSTs and acetylcholinesterase AChE, as indicative criteria. These two biomarkers were selected since they shown to be sensitive indicators of exposure to urban and industrial effluents in a previous biomonitoring program, performed with M. galloprovincialis, in the north coast of Portugal during 2000-2001 (Moreira et al. 2004).

To reach the main objective of this study, a field study was performed at two distinct sampling 
dates, 15 days and 1 year after the accident, along a presumed decreasing contamination gradient. In the first sampling date, it was observed that stations located closer to the accident point, particularly S1, presented higher and lower levels of GSTs and AChE activities, respectively, compared to the other stations. In addition, it is worth mentioning that mussels collected at $\mathrm{S} 3$ and $\mathrm{S} 4$, the latter considered as reference station, presented similar biomarker levels. Regarding GSTs, a 1.5 and a 1.3-fold increase on this activity was observed in mussels collected at S1 and S2, respectively, in relation to measured levels at the other stations. Considering the levels of AChE, a 2-fold decrease of its activity was observed at $\mathrm{S} 1$ and a 1.2-fold decrease at $\mathrm{S} 2$. Considering these results, it seems that the biomarkers used were able to monitor a spatial impact of the oil spill of at least $10 \mathrm{~km}$, confirming the higher level of contamination near the ship and a contamination gradient along the sampling stations. One year after the accident, such a contamination gradient was no longer evident since no significant differences in the levels of biomarkers were observed among the sampling stations, except for S1. Mussels sampled near the spillage presented higher levels of GSTs (2.1-fold) and lower levels of AChE (1.2-fold), comparing to the other stations. These results may suggest an exposure of mussels to compounds released at the time of the spill, and may reflect possible temporal sub-lethal effects due to this spill. Nevertheless, the possibility of other sources of contamination in this area, related to the proximity of Viana do Castelo harbour, must not be excluded.

The biomarker results obtained in the toxicity tests using the four elutriates are in accordance to the biomarker results obtained in the field, evidencing the existence of a contamination gradient along the coast due to the spillage. Furthermore, the comparison of the biomarker results obtained with elutriates $1 \mathrm{~A}$ and $1 \mathrm{~B}$ may clarify the field results observed at S1. Even though, significant alterations on GSTs and AChE levels were observed in both tests, a significant enhance of GSTs and an inhibition of AChE activities were noticed in mussels exposed to elutriate $1 \mathrm{~B}$ at lower percentages of elutriate tested $(6.25 \%)$ comparing to mussels exposed to elutriate A (25\%). These results further support the possibility of other sources of contamination in this area, in addition to the spillage.

Since acclimation period and laboratory test conditions may modify the biomarker responses, these parameters are non-negligible and must therefore, be taken into consideration. In fact, Khessiba et al. (2001) reported higher catalase (CAT) and malonedialdehyde (MDA) levels in $M$. galloprovincialis as a function of acclimation period, while no changes were detected in GSTs activity. Hoarau et al. (2001) observed a marked increased of GSTs activity in the clam Ruditapes decussatus after 2 weeks of acclimation. In this context, the influence of these parameters on the levels of GSTs and AChE was also investigated in the present study. Considering the results obtained, it seems that both acclimation period and test conditions had no marked influence on the two biomarkers studied, allowing a direct comparison of the levels measured in field with the levels obtained in the laboratory toxicity tests.

In vertebrates, induction of specific GSTs following exposure to diverse agents such as polycyclic aromatic hydrocarbons (PAHs) and polychlorinated biphenyls (PCBs) has been well documented (Armknecht et al., 1998; Stien et al., 1998; Willett et al., 1997). However, conflicting results have been reported regarding GSTs induction by these sorts of contaminants in mussels, particularly following exposure to PAH-type compounds (Akcha et al., 2000; Michel et al., 1993). In Mytilus spp., GSTs isoenzymes have already been purified and characterized (Fitzpatrick et al., 1995a, b; Fitzpatrick and Sheehan, 1993) and recent studies carried out with $M$. edulis showed that different GSTs isoforms are induced as a function of the nature of the pollutants (Fitzpatrick et al., 1997; Fitzpatrick and Sheehan, 1993). While some field studies have pointed out a good response of GSTs to organic pollution (Rodriguez-Ariza et al., 1993; Suteau et al., 1988; Kaaya et al., 1999; Willett et al., 1999; Gowland et al. 2002) others have detected little or no response (Porte et al., 2000). The discrepancies between these findings may be due to differences in the pollution type and load in each case. Gowland et al. (2002) reported an inducing of hepatopancreas GST activity in $M$. edulis populations from Loch Leven (west coast of Scotland) exposed to an effluent from an aluminum smelter containing PAHs. These authors found a 
correlation between GSTs and total PAHs burden and that high molecular weight PAHs (5- and 6ring) had a more pronounced role than low molecular weight compounds (2- to 4-ring) in inducing GST activity. In the present work, GSTs showed a consistent pattern of significant induction, both in field surveys and in laboratory toxicity tests, evidencing that GSTs were sensitive to the presence of a contamination gradient due to the spillage. Nevertheless, the controversial results observed in other field studies reveal that this potential biomarker of organic pollution and PAHs exposure needs further development before implementation in biomonitoring programs.

Due to the fact that some species of mussels have polymorphic cholinesterases (ChE), and distinct forms may show different sensitivity to anti-cholinesterase agents, their use as a biomarker of exposure to neurotoxic compounds requires the biochemical characterization of the forms present in the species and in the tissues to be studied (Bocquené et al., 1997). ChE have already been characterized in several tissues of $M$. galloprovincialis, providing evidence that the occurring enzyme in gills and haemolymph is AChE (Mora et al., 1999; Moreira et al., 2001). AChE activity has been widely used as a biomarker of exposure to organophosphate and carbamate pesticides in several field studies (Escartín and Porte, 1997; Radenac et al., 1998). Recently, several works evidence that other types of contaminants such as metals, surfactants (Martinez-Tabche et al., 1997; Najimi et al., 1997; Guilhermino et al., 1998) and compounds in complex mixtures (Payne at al., 1996) may also inhibit AChE activity. Moreover, several laboratory results supported the anticholinesterase effect of petroleum and PAH-type compounds (Kang and Fang, 1997; Martinez-Tabche et al., 1997; Akcha et al., 2000), although the mechanisms of this inhibition are not clear. In the present work, a significant inhibition of $\mathrm{AChE}$ was found both in the field study and in toxicity tests, allowing the detection of neurotoxicity in mussels exposed to the compounds released in the spillage.

For comparative purposes, standard acute bioassays were also performed using the brine shrimp $A$. franciscana and the rotifer $B$. plicatilis as test organisms. For both ecological and practical reasons, and because of their sensitivity to many chemicals, both Artemia and rotifers have long been considered as well suited organisms in aquatic testing (Persoone and Wells, 1987; ASTM, 1991; Van Steertegem and Persoone, 1993; Snell and Janssen, 1998). In accordance, a standardized protocol for estimating acute toxicity using the rotifer B. plicatilis has long been established (ASTM, 1991). In the seventies, acute toxicity testing with the brine shrimp Artemia was formally endorsed by the European Communities to regulate the discharges of wastes from the titanium dioxide industry (EC, 1978). Artemia and Brachionus cyst-based toxicity tests are now available, under the name of Artoxkit ${ }^{\mathrm{TM}}$ and Rotoxkit-M $\mathrm{M}^{\mathrm{TM}}$, respectively, for cost-effective routine screening of contamination in estuarine and marine environments. Nevertheless, all bioassays performed in this study, either with water and elutriate test samples, were unable to detect harmful effects induced by the oil spill. In this particular case and considering the results obtained, it was possible to conclude that the biomarker approach, which allowed the detection of a spatial and at a certain extent, a temporal impact, represented a more powerful and effective tool for assessing the effects of the spillage in comparison to the mortality endpoint of the standard bioassays.

In summary, the results obtained in this work showed that the biomarkers GSTs and AChE in $M$. galloprovincialis were sensitive indicators of exposure to this kind of pollution. The approach used in this work can be improved in the future by integrating other biomarkers (sub-individual and individual), in order to provide a better picture of the oil spill impact. Although inconsistent results have been reported over the last years regarding cytochrome P450 system in molluscs (Solé et al., 1996; Porte et al., 2001a) the use of the cytochrome P450 induction in mussels as a marker of oil exposure is supported by previous laboratory and field studies (Michel et al., 1993; Peters et al. 1999; Porte et al. 2000). Several alterations in specific aspects of cellular structure and function have also been described as responses to oil and PAH-type compounds exposure. Lysosomal alterations, such as lysosomal enlargement and lysosomal membrane destabilization, peroxisome proliferation and epithelial thinning of digestive cells in mussel hepatopancreas are among the most common cellular alterations described in the literature (Cajaraville 
et al., 1997; Lowe et al., 1981; Cajaraville et al., 2000; Fernley et al., 2000). Changes in M. edulis immune parameters, such as a reduced superoxide generation and phagocytic activity in mussel haemocytes, have been reported after the 'Sea Empress' oil spill (Milford Haven, Wales, UK) (Dyrynda et al., 2000). At the individual level, the measurement of physiological responses, such as feeding impairment and reduction of the scope for growth have been successfully applied as ecological relevant sublethal responses to toxicant exposure, and their integration by means of physiological energetics may provide important insights on growth and reproductive disruption at population level (Maltby et al., 2001). Several authors advocate the use of a battery of biomarkers, for providing a more robust indication of sub-lethal significant impacts, and there have been attempts to develop integrated models based on biomarker responses to generate indexes for quality assessment for the coastal environment (Narbonne et al., 1999). As pointed out by Fossi et al. (1994), a biomarker approach can be used in the integration of different episodes of temporal and spatial chemical exposure, representing rapid responses to toxicant exposure and as an outcome, providing an early warning signal of longterm effects that may occur later at higher levels of organization. However, as a result of being endpoints at a low level of biological organization, the biological significance of a biomarker response at higher levels of biological organization, especially at population and community levels, is uncertain and its questionable ecological relevance is undoubtedly the main limitation for its use in environmental monitoring programs. Nevertheless, as a feature of its rapid responsiveness and sensitivity to chemical contamination, biomarkers can be used in a predictive way as components of environmental monitoring programs, allowing the initiation of bioremediation strategies before irreversible environmental disturbances of ecological consequences occur. As a final consideration, the results of this study highlight the potential suitability of a biomarker approach for assessing spatial and temporal impacts of marine pollution accidents, such as fuel oil spills, suggesting the inclusion of biomarkers in risk assessment studies, as cost-effective and early warning recognized tools.

\section{Acknowledgements}

S.M. Moreira is a recipient of a $\mathrm{PhD}$. grant from Fundação para a Ciência e a Tecnologia (Portugal) (reference: SFRH/BD/5343/2001). This work was partially funded by Fundação para a Ciência e a Tecnologia (project CONTROL, contract: PDCTM/MAR/15266/99). Authors wish to thank B.B. Castro, M. Frasco, S. Gonzaga and B. Nunes, for assistance during fieldwork.

\section{References}

ASTM (1991). Standard guide for acute toxicity test with the rotifer Brachionus. In Annual Book of ASTM Standards, Vol. 11.04, E 1440. USA: American Society for Testing and Materials, Philadelphia, pp. 1-7.

Akcha, F., Izuel, C., Venier, P., Budzinski, H., Burgeot, T., and Narbonne, J.-F. (2000). Enzymatic biomarker measurement and study of DNA adduct formation in benzo[a]pyrene contaminated mussels, Mytilus galloprovincialis. Aquat. Toxicol. 49, 269-287.

Armknecht, S.L., Kaattari, S.L., and Van Veld, P.A. (1998). An elevated glutathione S-transferase in creosate-resistant mummichog (Fundulus heteroclitus). Aquat. Toxicol. 41, 116.

Beliaeff, B., O'Connor, T.P., Daskalakis, D.K., and Smith, P.J. (1997). U.S. mussel watch data from 1986 to 1994: temporal trend detection at large spatial scales. Environ. Sci. Technol. 31, 1411-1415.

Bocquené, G., Roig, A., and Fournier, D. (1997). Cholinesterases from the common oyster (Crassostrea gigas). Evidence for the presence of a soluble acetylcholinesterase insensitive to organophosphate and carbamate inhibitors. FEBS Lett. 407, 261-266.

Bradford, M. (1976). A rapid and sensitive method for the quantification of microgram quantities of protein utilizing the principle of protein dye binding. Anal. Biochem. 72, 248-254.

Bucheli, T.D., and Fent, K. (1995). Induction of cytochrome P450 as a biomarker for environmental contamination in aquatic ecosystems. Critic. Rev. Environ. Sci. Technol. 25, 201-268.

Cajaraville, M.P., Bebianno, M.J., Blasco, J., Porte, C., Sarasquete, C., and Viarengo, A. (2000). The use of biomarkers to assess the impact of pollution in coastal environments on the Iberian Peninsula: a practical approach. Sci. Total Environ. 247, 295-311.

Cajaraville, M.P., Orbea, A., Marigómez, I., and Cancio, I. (1997). Peroxisome proliferation in the digestive epithelium of mussels exposed to the water accommodated fraction of three oils. Comp. Biochem. Physiol. C 117, 233-242.

Clark, R.B. (1986). Consequences of oil pollution. In R.B. Clark (ed). Marine Pollution. Oxford, UK: Clarendon Press pp. $47-66$.

Clark, A.G. (1989). The comparative enzymology of the glutathione S-transferases from non-vertebrate organisms. Comp. Biochem. Physiol. B 92, 419-446. 
DIN (1985). German Standard Methods for the Examination of Water, Waste and Sludge - Sludge and Sediments, determination of leachability by water. DIN 38414 - S4, 6 pp.

Dyrynda, E.A., Law, R.J., Dyrynda, P.E.J., Kelly, C.A., Pipe, R.K., and Ratcliffe, N.A. (2000). Changes in immune parameters of natural mussel Mytilus edulis populations following a major oil spill ('Sea Empress', Wales, UK). Mar. Ecol. - Prog. Ser. 206, 155-170.

EC (1978). Council Directive 78/176/EEC on the Regulation of Discharges of Wastes from the Titanium Dioxide Industry. OJ L54/19. Brussels: Commission of the European Community.

Ellman, G.L., Courtney, K. D., Andres, V., and Featherstone, R.M. (1961). A new and rapid colorimetric determination of acetylcholinesterase activity. Biochem. Pharmacol. 7, 88-95.

Escartín, E. and Porte, C. (1997). The use of cholinesterase and carboxylesterase activities from Mytilus galloprovincialis in pollution monitoring. Environ. Toxicol. Chem. 16, 20902095.

Fernley, P.W., Moore, M.N., Lowe, D.M., Donkin, P., and Evans, S. (2000). Impact of the Sea Empress oil spill on lysosomal stability in mussel blood cells. Mar. Environ. Res. 50, 451-455.

Fitzpatrick, P.J., Krag, T.O.B., Hojrup, P., and Sheehan, D. (1995a). Characterization of a glutathione S-transferase and a related glutathione-binding protein from gill of the blue mussel, Mytilus edulis. Biochem. J. 305, 145-150.

Fitzpatrick, P.J., O'Halloran, J., Sheehan, D., and Walsh, A.R. (1997). Assessment of a glutathione S-transferase and related proteins in the gill and digestive gland of Mytilus edulis (L.), as potential organic pollution biomarkers. Biomarkers 2, 51-56.

Fitzpatrick, P.J., and Sheehan, D. (1993). Separation of multiple forms of glutathione S-transferases from the blue mussel, Mytilus edulis. Xenobiotica 23, 851-861.

Fitzpatrick, P.J., Sheehan, D., and Livingstone, D.R. (1995b). Studies on isoenzymes of glutathione S-transferase in the digestive gland of Mytilus galloprovincialis with exposure to pollution. Mar. Environ. Res. 39, 241-244.

Fossi, M.C., Leonzio, C., and Peakall, D.B. (1994). The use of nondestructive biomarkers in the hazard assessment of vertebrate populations. In Fossi, M.C., and Leonzio, C (ed). Nondestructive biomarkers in vertebrates. Lewis Publisher, Florida, USA.

Frasco, M.F., and Guilhermino, L. (2002). Effects of dimethoate and beta-naphthoflavone on selected biomarkers of Poecilia reticulata. Fish Physiol. Biochem. 26, 149-156.

Goldberg, E.D., Bowen, V.T., Farrington, J.W., Harvey, G., Martin, J.H., Parker, P.L., Risebrough, R.W., and Robertson, W. (1975). The mussel watch. Mar. Pollut. B. 5, $101-126$

Gowland, B.T.G., McIntosh, A.D., Davies, I.M., Moffat, C.F., Webster, L. (2002). Implications from a field study regarding the relationship between polycyclic aromatic hydrocarbons and glutathione S-transferase activity in mussels. Mar. Environ. Res. 54, 231-235.

Guillard, R.R.L. (1983). Culture of phytoplankton for feeding marine invertebrates. In C.J. Berg Jr. (ed). Culture of Marine
Invertebrates. Pensylvania, USA: Hutchinson-Ross, pp. 108-132.

Guilhermino, L., Barros, P., Silva, M.C., and Soares, A.M.V.M. (1998). Should the use of cholinesterases as a specific biomarker for organophosphate and carbamate pesticides be questioned? Biomarkers 3, 157-163.

Guilhermino, L., Lopes, M.C., Carvalho, A.P., and Soares, A.M.V.M. (1996). Inhibition of acetylcholinesterase activity as effect criterion in acute tests with juvenile Daphnia magna. Chemosphere 32, 727-738.

Habig, W.H., Pabst, M.J., and Jakoby, W.B. (1974). Glutathione S-transferases - the first enzymatic step in mercapturic acid formation. J. Biol. Chem. 249, 7130-7139.

Hoarau, P., Gnassia-Barelli, M., Romeo, M., and Girard, J.-P. (2001). Differential induction of glutathione S-transferases in the clam Ruditapes decussatus exposed to organic compounds. Environ. Toxicol. Chem. 20, 523-529.

Kaaya, A., Najimi, S., Ribera, D., Narbonne, J.F., and Moukrim, A. (1999). Characterization of glutathione Stransferases (GST) activities in Perna perna and Mytilus galloprovincialis used as a biomarker of pollution in the Agadir Marine Bay (South of Morocco). Bull Environ. Contam. Toxicol. 62, 623-629.

Kang, J.-J., and Fang, H.-W. (1997). Polycyclic aromatic hydrocarbons inhibit the activity of acetylcholinesterase purified from electric eel. Biochem. Biophy. Res. Communications 238, 367-369.

Khessiba, A., Hoarau, P., Gnassia-Barelli, M., Aissa, P., and Roméo, M. (2001). Biochemical response of the mussel Mytilus galloprovincialis from Bizerta (Tunisia) to chemical pollutant exposure. Arch. Environ. Contam. Toxicol. 40, 222-229.

Lowe, D.M., Moore, M.N., and Clarke, K.R. (1981). Effects of oil on digestive cells in mussels: quantitative alterations in cellular and lysosomal structure. Aquat. Toxicol. 1, 213-226.

Maltby, L., Kedwards, T.J., Forbes, V.E., Grasman, K., Kammenga, J.E., Munns, W.R., Ringwood, A.H., Weis, J.S., and Wood, S.N. (2001). Linking individual-level responses and population-level consequences. In D.J. Baird, and Jr. Burton G.A. (eds). Ecological variability: separating natural from antropogenic causes of ecosystem impairment. Florida, USA: SETAC Press.

Martinez-Tabche, L., Mora, B.R., Faz, C.G., Castelan, I.G., Ortiz, M.M., Gonzalez, V.U., and Flores, M.O. (1997). Toxic effect of sodium dodecylbenzenesulfonate, lead, petroleum, and their mixtures on the activity of acetylcholinesterase of Moina macrocopa in vitro. Environ. Toxicol. Water Qual. 12, 211-215.

Michel, X.R., Suteau, P., Robertson, L.W., and Narbonne, J.F. (1993). Effects of benzo(a)pyrene, 3,3',4,4'- tetrachlorobiphenyl and $2,2^{\prime}, 4,4^{\prime}, 5,5^{\prime}$ - hexachlorobiphenyl on the xenobiotic-metabolizing enzymes in the mussel (Mytilus galloprovincialis). Aquat. Toxicol. 27, 335-344.

Mora, P., Fournier, D., and Narbonne, J.-F. (1999). Cholinesterases from the marine mussels Mytilus galloprovincialis $\mathrm{LmK}$. and $M$. edulis L. and from the freshwater bivalve Corbicula fluminea Müller. Comp. Biochem. Physiol. C 122, 353-361. 
Moreira, S.M., Coimbra, J., and Guilhermino, L. (2001). Acetylcholinesterase of Mytilus galloprovincialis LmK. haemolymph: a suitable environmental biomarker. Bull. Environ. Contam. Toxicol. 67, 470-475.

Moreira, S.M., and Guilhermino, L. (2004). The use of mytilus galloprovincialis acetylcholinesterase and glutathione Stransferases activities as biomarkers of environmental contamination along the northwest Portuguese coast. Environmental monitoring and Assessment (in press).

Najimi, S., Bouhaimi, A., Daubèze, M., Zekhnini, A., Pellerin, J., Narbonne, J.-F., and Moukrim, A. (1997). Use of acetylcholinesterase in Perna perna and Mytilus galloprovincialis as a biomarker of pollution in Agadir marine bay (South of Morocco). B. Environ. Contami. Toxicol. 58, 901-908.

Narbonne, J.F., Daubèze, M., Clérandeau, C., and Garrigues, P. (1999). Scale of classification based on biochemical biomarkers in mussels: application to pollution monitoring in European coasts. Biomarkers 4, 415-424.

Payne, J.F., Mathieu, A., Melvin, W., and Fancey, L.L. (1996). Acetylcholinesterase, an old biomarker with a new future? Field trials in association with two urban rivers and a paper mill in Newfoundland. Mar. Pollut. B. 32, 225-231.

Peakall, D. (1992). Animal Biomarkers as Pollution Indicators. London, England: Chapman \& Hall.

Persoone, G., and Wells, P.G. (1987). Artemia in aquatic toxicology: a review. In P. Sorgeloos, D.A. Bengtson, W. Decleir, and E. Jaspers. (eds). Artemia Research and its Applications, Vol. 1 - Morphology, Genetics, Strain Characterization, Toxicology. Wetteren, Belgium: Universa press, pp. 259-275.

Peters, L.D., Shaw, J.P., Nott, M., O'Hara, S.C.M., and Livingstone, D.R. (1999). Development of cytochrome P450 as a biomarker of organic pollution in Mytilus sp.: field studies in United Kingdom ('Sea Empress' oil spill) and the Mediterranean Sea. Biomarkers 4, 425-441.

Porte, C., Biosca, X., Solé, M., and Albaigés, J. (2000). The Aegean Sea oil spill on the Galician Coast (NW Spain). III: the assessment of long-term sublethal effects on mussels. Biomarkers 5, 436-446.

Porte, C., Biosca, X., Solé, M., and Albaigés, J. (2001a). The integrated use of chemical analysis, cytochrome P450 and stress proteins in mussels to assess pollution along the Galician Coast (NW Spain). Environ. Pollut. 112, 261-268.

Porte, C., Solé, M., Borghi, V., Martinez, M., Chamorro, J., Torreblanca, A., Ortiz, M., Orbea, A., Soto, M., and Cajaraville M.P. (2001b). Chemical, biochemical and cellular responses in the digestive gland of the mussel Mytilus galloprovincialis from the Spanish Mediterranean coast. Biomarkers 6, 335-350.

Radenac, G., Bocquené, G., Fichet, D., and Miramand, P. (1998). Contamination of a dredged-material disposal site ( $\mathrm{La}$ Rochelle Bay, France). The use of the acetylcholinesterase activity of Mytilus edulis (L.) as a biomarker of pesticides: the need for a critical approach. Biomarkers 3, 305-315.

Rodriguez-Ariza, A., Martinez-Lara, E., Pascual, P., Pedrajas, J.R., Abril, N., Dorado, G., Toribio, F., Barcena, J.A., Peinado, J., Pueyo, C., and Lopes-Barea, J. (1993). Bio- chemical and genetic indices of marine pollution in Spanish littoral. Sci. Tot. Environ. Supplies 93, 109-113.

Snell, T.W., and Janssen, C.J. (1998). Microscale toxicity testing with rotifers. In P.G. Wells and C. Blaise (eds). Microscale Testing in Aquatic Toxicology: Advances, Techniques, and Practice. Florida, USA: Lewis Publishers, Boca Raton, pp. 409-422.

Solé, M., Porte, C., Biosca, X., Mitchelmore, C.L., Chipman, J.K., Livingstone, D.R., and Albaigés, J. (1996). Effects of the 'Aegean Sea'oil spill on biotransformation enzymes, oxidative stress and DNA-adducts in digestive gland of the mussel (Mytilus edulis L.). Comp. Biochem. Physiol. 113C, 257-265.

SOP (1990). Artemia Toxicity Screening Test for Estuarine and Marine Waters. Creasel, Deinze, Belgium: Standard Operation Procedure, $22 \mathrm{pp}$.

SOP (1994). Rotifer Toxicity Screening Test for Estuarine and Marine Waters. Creasel, Deinze, Belgium: Standard Operation Procedure, $23 \mathrm{pp}$.

Stien, X., Percic, P., Gnassia-Barelli, M., Roméo M., and Lafaurie, M. (1998). Evaluation of biomarkers in caged fishes and mussels to assess the quality of waters in a bay of the NW Mediterranean Sea. Environ. Pollut., 99, 339-345.

Suteau, P.M., Daubeze, M., Migaud, M.L., and Narbonne, J.F. (1988). PAH-metabolizing enzymes in whole mussels as biochemical tests for chemical pollution monitoring. Mar. Ecol. Prog. Ser. 46, 45-49.

Thompson, H.M. (1999). Esterases as markers of exposure to organophosphates and carbamates. Ecotoxicology 8, 369384.

Van Steertegem, M., and Persoone, G. (1993). Cyst-based toxicity tests. V. Development and critical evaluation of standardized toxicity tests with the brine shrimp Artemia (Anostraca, Crustacea). In A.M.V.M. Soares and P. Calow. (eds). Progress in Standardization of Aquatic Toxicology Tests. Boca Raton, Florida, USA: Lewis Publishers, pp. 8197.

Veldhuizen-Tsoerkan, M.B., Holwerda, D.A., Bont, A.M.T., Smaal, A.C., and Zandee, D.I. (1991). A field study on stress indices in the sea mussel, Mytilus edulis: application of the "stress approach" in biomonitoring. Arch. Environ. Contam. Toxicol. 21, 497-504.

Viarengo, A., and Canesi, L. (1991). Mussel as biological indicators of pollution. Aquaculture 94, 225-243.

Willett, K.L., McDonald, S.J., Steinberg, M.A., and Beatty, K.B. (1997). Biomarker sensitivity for polynuclear aromatic hydrocarbon contamination in two marine fish species collected in Galveston Bay, Texas. Environ. Toxicol. Chem. 16, 1472-1479.

Willett, K.L., Wilson, C., Thomsen, J., Porter, W. (1999). Evidence for and against the presence of polynuclear aromatic hydrocarbon and 2,3,7,8-tetrachloro- $p$-dioxin binding proteins in the marine mussels, Bathymodiolus and Modiolus modiolus. Aquat. Toxicol. 48, 51-64.

Zar, J.H. (1996). Biostatistical Analysis. New Jersey, USA: Prentice Hall International Editions. 